\title{
Review of International Studies
}

VOLUME 18 NUMBER 1 JANUARY 1992

EDITOR: RICHARD LITTLE 
Review of International Studies

VOLUME 18. NUMBER 1. JANUARY 1992

\section{CONTENTS}

Notes on contributors

The regulation of diplomatic practice: the beginnings to the Vienna

Convention on Diplomatic Relations, 1961

RICHARD LANGHORNE

International ethics and international law

TERRY NARDIN

States and the future of global finance

ERIC HELLEINER

The possibility of judgement: moralizing and theorizing in international relations

KIMBERLY HUTCHINGS

Review Article

Evan Luard as a writer on international affairs

ADAM ROBERTS

Reply

Western intelligence, the Soviet threat and NSC-68: a reply to Beatrice Heuser MICHAEL COX

A rejoinder to Michael Cox

BEATRICE HEUSER 